\title{
NATIONALISM AND REGIONALISM IN COLONIAL INDONESIA: THE CASE OF MINAHASA
}

\author{
David Henley
}

The "regional nationalisms" of the early twentieth-century Netherlands East Indies are usually portrayed as mere subcomponents of the emerging Indonesian nationalist movement. Akira Nagazumi's authoritative work on the first ten years of Budi Utomo, for instance, is entitled The Dawn of Indonesian Nationalism. ${ }^{1}$ Yet this Javanese nationalist organization consistently refused to embrace the outer islands-tanah sabrang, the lands overseasduring the period in question. Parallel movements such as the Sundanese association Pasundan and the Ambonese Sarekat Ambon, both of which maintained their separate identities even after the eventual fusion of Budi Utomo into the Indonesian party Parindra in 1935, also tend to be characterized in the historical literature as "local," "regional," or "ethnic" tributaries of the Indonesian nationalist current. ${ }^{2}$ Even where the persistence of exclusive local nationalisms is admitted, they are dismissed either as expressions of "primordial" ethnic loyalty or as conservative reactions by privileged minority groups against the Indonesian nationalist attack on the colonial order. ${ }^{3}$

As Benedict Anderson has pointed out, the common assumption that the boundaries of the colonial state as a whole define the only frontiers appropriate to an anticolonial nation-

This article draws upon the author's 1992 Australian National University PhD thesis, "Nationalism and Regionalism in a Colonial Context: Minahasa in the Dutch East Indies."

${ }^{1}$ Akira Nagazumi, The Dawn of Indonesian Nationalism: the Early Years of Budi Utomo, 1908-1918 (Tokyo: Institute of Developing Economies, 1972).

2 For instance: J.T.P. Blumberger, De nationalistische beweging in Nederlandsch-Indië (Haarlem: Willink, 1931), p. 41; H. Bouman, Enige beschouwingen over de ontwikkeling van het Indonesisch national isme op Sumatra's westkust (Groningen: Wolters, 1949), p. 31; H.A.J. Klooster, Indonesiërs schrijven hun geschiedenis (Dordrecht: Foris, 1985), p. 32; J.M. Pluvier, Overzicht van de ontwikkeling der nationalistische beweging in Indonesia in de jaren 1930 tot 1942 (The Hague: Van Hoeve, 1953), p. 81; Merle C. Ricklefs, A History of Modern Indonesia (London: Macmillan, 1981), p. 159.

${ }^{3}$ See, for instance: Pluvier, Overzicht, p. 15; Clifford Geertz, "The Integrative Revolution: Primordial Sentiments and Civil Politics in the New States," in Old Societies and New States, ed. C. Geertz (New York: Free Press of Glencoe, 1963), p. 111. 
alism is not universally valid. The Vietnamese pioneers of nationalism in French Indochina, for instance, never came to accept Cambodians and Laotians as compatriots, with the result that the colony disintegrated into three independent nations. ${ }^{4}$ Dismissive attitudes toward the regional nationalisms of the Netherlands Indies are inspired in part by a teleological projection of postwar Indonesian realities back into the colonial period. But Indonesia before 1942, as Tony Reid has observed, "was less clearly or consciously a nation than most colonies." 5 This is not to suggest that fissiparous tendencies were ever as strong in the Dutch colony as in Indochina. Nevertheless, there was at least one area, Minahasa in North Sulawesi, where a modern nationalism with autonomous historical roots developed parallel to, rather than as component of or even a reaction against, Indonesian nationalism.

A nation can be characterized as a perceived community defined with respect to a home territory and imbued with a range of powerful social and political ideals. ${ }^{6}$ Such ideals may be couched partly in religious terms, but they almost always include the secular objectives of social unity, material and intellectual progress, and collective autonomy in cultural and, above all, political spheres. A degree of conceptual equality between all the members of the national community-even those, numerous in emerging colonized nations, who do not yet perceive that community themselves-is also inherent in the concept of nationhood, and this is often manifested in a desire for political democracy as well as national independence. This article outlines the processes by which Minahasa acquired the characteristics of a nation as a result of, and a reaction to, Dutch colonialism. Although they began at earlier dates and operated on a smaller scale, these processes were similar in many cases to the ones which gave rise to Indonesian nationalism.

I will first describe how Minahasa was defined in the seventeenth and eighteenth centuries as a territorial unit isolated by colonial boundaries from its socioeconomic environment. The initial fragmented ethnic and political situation within this territory is then outlined, and the evolution of a perceived Minahasan community during the nineteenth century explained in terms of Christianization and the impact of colonial administrative and educational institutions. Mission and government personnel also helped to imbue the emerging community with ideals of social unity and economic progress. Because of the racial stratification inherent in the colonial system, however, the Minahasan group defined itself partly in contradistinction and even opposition to the European community. The fact that Minahasans became a subaltern colonial elite themselves as officials and soldiers elsewhere in the Indies enhanced their sense of exclusive Minahasan identity even if it complicated their relationship with the Dutch.

Further sections of the article will deal with the emergence of Minahasan nationalism as a political movement, the contribution of Christianity to that movement, the historical parallels between Dutch Minahasa and the colonial Philippines, and the Minahasan view of Indonesian nationalism. The tension between Minahasan nationalism and its Indonesian counterpart was resolved, at least to the satisfaction of leading Minahasan political figures, by the idea of an independent Indonesian commonwealth in which each ethnic nation or

\footnotetext{
4 Benedict R. O'G. Anderson, Imagined Communities: Reflections On The Origin And Spread Of Nationalism (London: Verso, 1983), pp. 113-20.

5 Anthony Reid, "The Revolution In Regional Perspective," in The Indonesian Revolution: Conference Papers, Utrecht, 17-20 June 1986 (Utrechtse Historische Cahiers 7 No. 2-3, 1986), p. 196.

${ }^{6} \mathrm{My}$ interpretation of the nation as a generic concept is inspired mainly by Anderson's Imagined Communities, E. Gellner's Nations and Nationalism (Oxford: Blackwell, 1983), and A. D. Smith's The Ethnic Origins of Nations (Oxford: Blackwell, 1986).
} 
bangsa, including bangsa Minahasa, would retain political autonomy within a federal framework. A final section of the article briefly compares Minahasan regional nationalism with some parallel movements elsewhere in colonial Indonesia, and tentatively suggests a framework within which variations in the strength of such movements might be explained.

\section{Minahasa as a Territorial Unit}

The territorial basis for the Minahasan nation was established in the seventeenth and eighteenth centuries, when a mountainous area of about 4,800 square kilometers at the tip of the northern peninsula of Sulawesi was isolated from its immediate environment by a series of conflicts and treaties which brought it under the exclusive suzerainty of the VOC. ${ }^{7}$ The Dutch objective here was to extract rice from the fertile uplands around Lake Tondano with which to feed VOC garrisons in the nearby Moluccas. They thus needed to release the ricecultivating communities from the control of the Spanish, who had been active in the area intermittently for some decades, and from the influence of a local "king"-raja, datu, or kolano - who dominated the coastlands around Manado and had previously mediated relations with the highlands. 8

The Castilians were duly expelled in 1660 , and in 1679 a combination of military pressure and commercial opportunity led leaders of "the entire community of the landstreek van Manado, or the northernmost part of Celebes" to conclude a treaty with the VOC, in which they renounced their allegiance to the king and declared themselves Company vassals. ${ }^{9}$ Formerly peripatetic, the king and his successors were now restricted to Bolaang, 100 kilometers down the coast from the VOC fort in Manado. ${ }^{10}$ In 1756 a rigorous border agreement separated the Dutch zone from the domain of the king, which included the Mongondow highlands. ${ }^{11}$ Like the other small principalities of North Sulawesi, what became known as the kingdom of Bolaang-Mongondow was then left in substantial independence by the Dutch until the twentieth century. The landstreek van Manado, by contrast, became an isolated island of directly ruled colonial territory called Minahasa.

The word minahasa means "united, become one."12 When it first appears in Dutch documents in 1789 , it refers to the council of chiefs from different parts of the territory convened at intervals by the VOC to receive instructions and resolve internal disputes. ${ }^{13}$ The landstreek van Manado contained some twenty-seven separate political units, each relating

\footnotetext{
7 The standard source for the early history of Dutch involvement in Minahasa is E. C. Godée Moslbergen, Geschiedenis van de Minahassa tot 1829 (Weltevreden: Landsdrukkerij, 1928).

${ }^{8}$ Early Spanish activities in North Sulawesi are described in: S. Stokman, "De missies der minderbroeders op de Molukken, Celebes en Sangihe in de XVI en XVII eeuw," Collectanea Franciscana Neerlandica 2 (1931): 499-556; C. Wessels, De katholieke missie in de Molukken, Noord-Celebes en de Sangihe-eilanden gedurende de Spaansche bestuursperiode, 1606-1677 (Tilburg: Bergmans, 1935). W. Dunnebier outlines the history of the local dynasty in "Over de vorsten van Bolaang Mongondow," Bijdragen tot de Taal-, Land-en Volkenkunde van Nederlandsch-Indië [hereafter BKI] 105 (1949): 219-74.

${ }^{9}$ Godée Molsbergen reproduces the 1679 treaty in Geschiedenis van de Minahassa (pp. 55-58).

${ }^{10}$ Dunnebier, "Over de vorsten van Bolaang Mongondow," p. 244; Godée Molsbergen, Geschiedenis van de Minahassa, p. 103; R. Padtbrugge, "Het journaal van Padtbrugge's reis naar Noord-Celebes en de Noordereilanden" [1677], BKI 14 (1867): 105-340, p. 132.

11 Godée Molsbergen, Geschiedenis van de Minahassa, p. 119.

12 J.A.T. Schwarz, Tontemboansch-Nederlandsch woordenboek met Nederlandsch-Tontemboansch register (Leiden: Brill, 1908), p. 46.

13 Godée Molsbergen, Geschiedenis van de Minahassa, pp. 135, 137, 139.
} 
independently to the Dutch authorities. ${ }^{14}$ The majority of these groups, known as walak, were communities defined by a combination of features including cultural homogeneity, loose territoriality, recognition of a single leadership, and a strong but partly fictive tradition of common descent. ${ }^{15}$ Attempts by the VOC to appoint paramount chiefs for the whole region had failed due to endemic rivalries between the walak, rivalries constantly inflamed by the traditional practice of headhunting. ${ }^{16}$ In the eighteenth century, the power of the small Dutch presence to alter traditional institutions remained limited.

After the replacement of the VOC by colonial government proper, however, this situation quickly began to change. In 1809, Dutch forces crushed a serious rebellion by a number of walak at Tondano. ${ }^{17}$ In 1822 the compulsory cultivation of coffee, for which climate and soil in the uplands were ideal, was introduced on a large scale. This made the intensification of colonial administration both economic and necessary, and ultimately led to the transformation of the walak leaders into a bureaucratic corps trained, directed, and paid by the Dutch. ${ }^{18}$ It was during this period that the term Minahasa came to designate the whole territory within which a miniature colonial state was being created. ${ }^{19}$

\section{Ethnic Diversity in Precolonial Minahasa}

Precolonial Minahasa-if the anachronism may be excused-had been culturally diverse as well as politically fragmented. At least eight mutually unintelligible languages, for instance, were spoken within it. ${ }^{20}$ Among three of the largest language groups, however, there was already some awareness of common belonging. The various walak speaking the Tontemboan, Tombulu, and Tonsea languages were all believed to have developed, by way of a series of divisions and migrations, from a single ancestral group. ${ }^{21}$ According to one common oral tradition, the progenitors of this group had been an incestuous mother and son, Lumimu'ut and To'ar. ${ }^{22}$ This perceived genealogical unity was also reflected in folk religion. At their initial separation, the Tontemboan, Tombulu, and Tonsea peoples had each been

14 J.G.F. Riedel, "De Minahasa in 1825: bijdrage tot de kennis van Noord-Celebes," Tijdschrift voor Indische Taal-, Land-en Volkenkunde [hereafter TBG] 18 (1872): 458-68, p. 459.

15 Attempts to reconstruct the walak from diverse Dutch sources can be found in: M. Schouten, "De veranderende positie van het walakhoofd in de Minahasa gedurende de 19e eeuw "(thesis, Vrije Universiteit, Amsterdam, 1978), pp. 23-31; B. Supit, Minahasa dari amanat Watu Pinawetengan sampai gelora Minawanua (Jakarta: Sinar Harapan, 1986), pp. 43-69.

${ }^{16}$ A fascinating eyewitness account of this violent society was recorded in 1679 by R. Padtbrugge, "Beschrijving van de zeden en gewoonten van de bewoners der Minahassa," BKI 13 (1866): 304-30.

17 Godée Molsbergen, Geschiedenis van de Minahassa, pp. 168-69; Supit, Minahasa, pp. 154-94; E. Mambu, "Jalannya Perang Tondano" (paper for the Seminar Perang Tondano, Jakarta, November 1986), pp. 56-81.

18 This process is the principal subject of Schouten's "De veranderende positie van het walakhoofd."

19 The earliest evidence of this usage is from 1822-see C.G.C. Reinwardt, Reis naar het oostelijk gedeelte van den Indischen Archipel in het jaar 1821 (Amsterdam: Muller, 1858), p. 583.

${ }^{20}$ Their approximate distributions are shown on the accompanying map. J.N. Sneddon is the main authority on these languages - see his Proto-Minahasan: Phonology, Morphology and Wordlist and Proto-Sangiric and the Sangiric Languages (Canberra: Department of Linguistics, Research School of Pacific Studies, Australian National University, 1978 and 1984).

21 Short histories of most of the walak, adapted from oral sources, are given by J.G.F. Riedel, Pada menjatakan babarapa perkara deri pada hhikajatnja tuwah tanah Minahasa sampej pada kadatangan orang kulit putih Nederlanda itu (Batavia: Landsdrukkerij, 1862), J.E. Jasper, "Historische verhalen en legenden van de Minahasa," Tijdschrift voor het Binnenlandsch Bestuur 50 (1916): 257-86, and A.M. Domsdorff, "De Minahasische dorpsgemeenschap in haar genetisch verband," Adatrechtbundels 34 (1937): 344-59.

22 J.A.T. Schwarz reproduces several versions of this story in Tontemboansche teksten, 2 vols. (Leiden: Brill, 1907) 2: 389-405. 


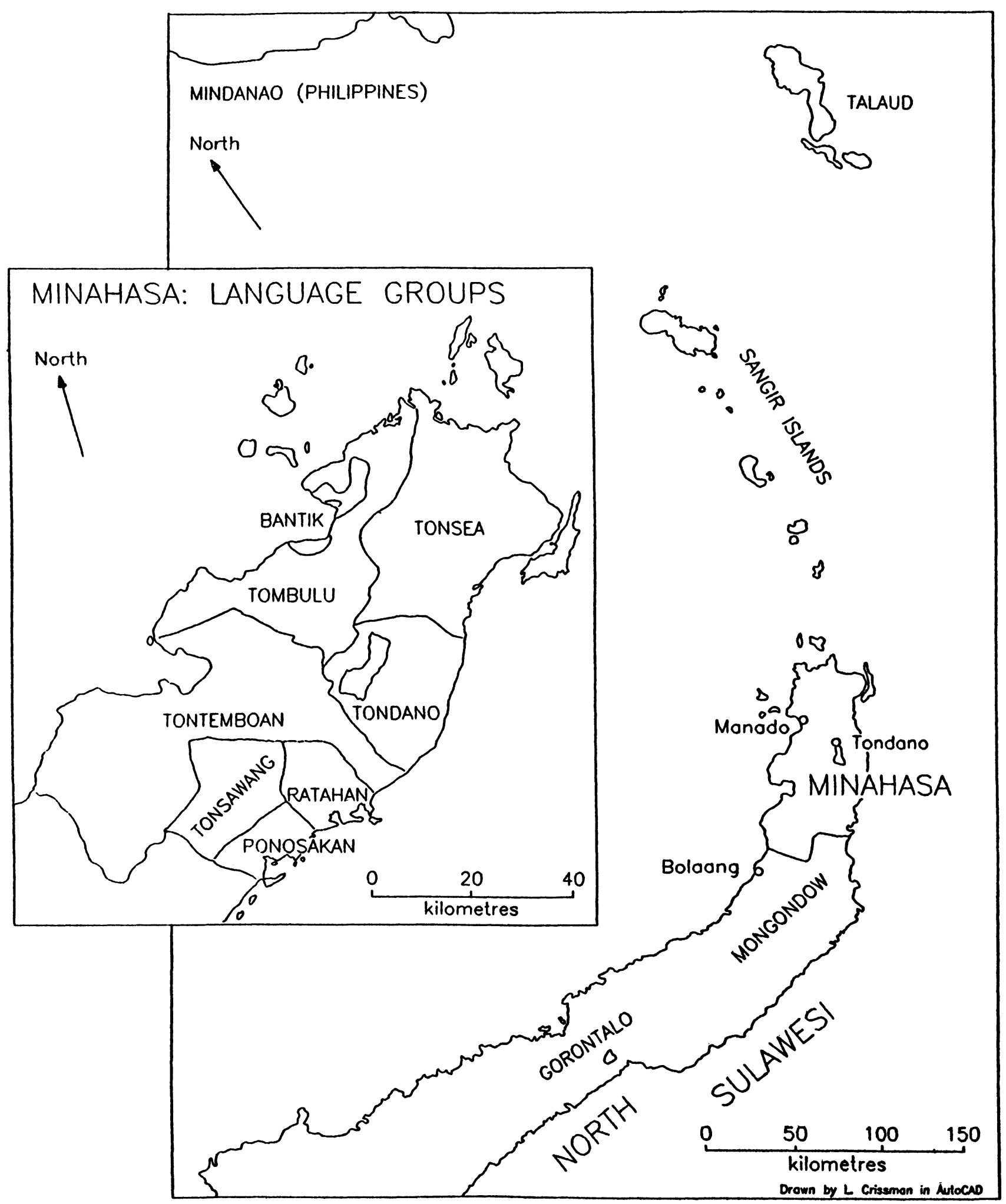


assigned slightly different ritual systems. ${ }^{23}$ The differences, however, were understood as complementary in a cosmic sense, and there was apparently at least one joint ritual in which this complementarity was acted out by participants from all three groups. ${ }^{24} \mathrm{~A}$ network of ritual experts certainly transcended both walak and language boundaries. 25

It has sometimes been argued on this basis that Minahasa was already a nation in precolonial times. ${ }^{26}$ There are several reasons to question this assertion. First, the tripartite ethnic core excluded more than one quarter of the population of the territory. ${ }^{27}$ The numerous Tondano language speakers, for instance, were considered outsiders who had been permitted to settle in the area only as "slaves of the Tonsea." 28 Even within the core groups, not all individuals traced their descent from To'ar and Lumimu'ut. ${ }^{29}$ Second, besides lacking the modern secular ideals usually associated with nationhood, the community was also without the basic corporate quality of a nation. It had, for instance, no name. Even the later name of Minahasa alludes to a former diversity now unified, not an ancestral unity now diversified. The religious emphasis was not upon unity, but upon systematic and necessary diversity. Common belonging was symbolized by the open vertical tree of descent, not the bounded horizontal field of nationality, and it entailed neither political solidarity nor any degree of social equality. Slavery, for example, was an important institution, and slaves could be obtained in the course of war between related groups. ${ }^{30}$ The elements of unity present in precolonial culture are best understood as latent resources upon which people would later draw to help create a new kind of community in Minahasa.

\section{Minahasa Becomes a Perceived Community}

The most conspicuous aspects of traditional religion-major ceremonies, sacred oral literature, senior ritual specialists-disappeared in the nineteenth century and were replaced by their Christian equivalents. Christianization had already begun in VOC and even Spanish times, but the great majority of Minahasans were converted between 1831 and 1891 by the NZG or Nederlandsch Zendeling Genootschap, the Dutch Missionary Society. ${ }^{31}$ The attraction of Protestant Christianity in this period can be explained partly by its association with the prestigious Dutch rulers, partly also by the erosion of old cultural institutions under new political pressures. Compulsory coffee cultivation and other colonial labor duties interfered with ritual activities and with the traditional agricultural cycle, to which those

\footnotetext{
23 Jasper, "Historische verhalen," pp. 262-63, 285; Riedel, Pada menjatakan babarapa perkara, pp. 15-16.

24 F.S.A. de Clercq, "Korte beschrijving der fosso Mahapansa zooals die voorheen gevierd werd door de Alifoeroe in de Minahasa," TBG (1870): 546-54.

25 K. Tauchmann, "Die Religion der Minahasa-Stämme" (doctoral thesis, Universität zu Köln, 1968), pp. 150-51, 172-74.

26 Most recently in ibid., pp. 46, 185-88.

27 Approximately 26,000 out of 89,000 in 1846 (Schouten, "De veranderende positie van het walakhoofd," pp. 11, 14).

28 N. Graafland, De Minahassa: haar verleden en haar tegenwoordige toestand, 2 vols. (2nd ed.; Batavia: Kolff, 1898), 1: 78-79.

${ }^{29}$ Schwarz (Tontemboansche teksten, 2: 408-10) reproduces a Tontemboan genealogy beginning with a different pair of mythical ancestors.

30 Riedel, "De Minahasa in 1825," p. 575; Graafland, De Minahassa, 1: 407, 422.

31 The history of Christianization in Minahasa is summarized by J. W. Gunning, "De protestantsche zending in de Minahasa," BKI 80 (1924): 451-520.
} 
activities were closely related..$^{32}$ The suppression of headhunting, the abolition of slavery, and the reconstruction of houses and settlements according to new plans had a similarly disruptive effect upon the old culture complex. ${ }^{33}$ A traditional admiration for strength and power, however, survived to motivate imitation of Dutch religious practices, which were assumed to be particularly efficacious. ${ }^{34}$ At the same time, the bureaucratic restructuring of the internal social hierarchy meant that sponsorship of traditional religious ceremonies ceased to confer influence or prestige. ${ }^{35}$

The process of Christianization was central to the emergence of a Minahasan national community, most importantly because it replaced the old cultural ideals of legitimate violence, systematic diversity, and natural inequality with one of peaceful and homogeneous unity. "The Christian religion shall eliminate all divisions," taught the NZG, "and all Minahasans shall truly become brothers." 36 Inevitably, the reality was never so perfect. Christian Minahasa, although pacified by colonialism, remained a land of intense personal and group rivalries. Nevertheless, the ideal of Minahasan unity was embraced wholeheartedly, and its appeal only seemed to be enhanced by the persistent discrepancy between ideal and reality.

Though this ideal was new, the missionaries attempted to promote it partly by harnessing the latent unity which they detected in traditional society and culture. NZG teaching material, for instance, stressed the cultural similarity and common origin of most walak, and also portrayed the Tondano language group-among whom, significantly, many of the earliest converts were made-as a fourth indigenous core group, equal in seniority to the Tombulu, Tontemboan, and Tonsea. ${ }^{37}$ At the effective cost of perpetuating ancestor worship, the missionaries even appropriated and promoted a version of the legend of To'ar and Lumimu'ut, whom they now portrayed as the ancestors of all Minahasans without exception. ${ }^{38}$

European interest in Minahasan tradition, however, was not entirely calculating. Many of the later missionaries, and some white government officials too, genuinely idealized what they perceived as the innocence and authenticity of the vanishing tribal society. ${ }^{39}$ This reflected both intellectual trends in Europe and a growing anxiety about what they saw as excessive cultural Westernization among Minahasans, whose imitation of Europeans had extended beyond religion to such things as fashion and drink. ${ }^{40}$ The missionaries sought to

\footnotetext{
32 In 1856, for instance, a Dutch restriction on the duration of religious ceremonies triggered a wave of conversion to Christianity in Tonsea (Graafland, De Minahassa, 2: 279-83).

${ }^{33}$ Many villages were rebuilt under state supervision after an earthquake in 1845 . Debt slavery was outlawed in 1822, chattel slavery in 1859. The last recorded headhunt took place in 1862 (ibid., 1: 86, 90, 514-16; Schouten, "De veranderende positie van het walakhoofd," p. 16).

34 The importance and religious ramifications of strength or keter in Minahasan culture are emphasized by $M$. Schouten in "The Minahasans: Eternal Rivalry," in Indonesia in Focus ed. N. Jonge, V. Dekker and R. Schefold (Meppel: Edu'Actief, 1988).

35 Tauchmann, Die Religion, pp. 215-26.

36 From an NZG schoolbook for Minahasans by N. Graafland, Inilah kitab batja akan tanah Minahasa (Rotterdam: Wijt, 1863), p. 24.

37 Graafland, Inilah kitab batja, pp. 22-24. Dutch readers, strikingly, were treated to a more complete story (Graafland, De Minahassa, 1: 78-80, 212-13).

38 The standardized version is presented by Graafland in De Minahassa, 1: 210-13. It was taught in NZG schools until well into the twentieth century (Supit, Minahasa, pp. 15, 19-22).

${ }^{39}$ Graafland, De Minahassa, 1: 204; J.G.F. Riedel, "De vroegere regten en verplichtingen der vrije alifoeroes van noord-Selebes,"TBG 18 (1872): 157-63, p. 157.

40 Graafland, De Minahassa, 2: 199, 349; H. van Kol, Uit onze koloniën (Leiden: Sijthoff, 1903), p.296.
} 
limit this process by fostering pride in the Minahasan identity itself. In doing so, they applied their own European assumptions about nationality, distinguishing "nationaal" customs and crafts from foreign borrowings. ${ }^{41}$ Some of the former-a form of structured labor exchange, a harvest dance, a style of rattan work-were deliberately standardized and promoted. ${ }^{42}$ Missionary education director Nicolaas Graafland even composed a patriotic song for Minahasan schoolchildren:

Minahasa yang tercinta
Dengar kidung hatiku
Karena untungmu kuminta
Limpah berkat pada Hu
Mana dapat jauh dan rapat
Tanah lebih elok trang?
Tagal itu sabagitu
Beta cinta engkau grang. ${ }^{43}$

Beloved Minahasa

Hear my heart's song

For your good fortune

I ask God's great blessing

Where is there a lovelier

More tranquil land?

Because there is none I love you with passion.

The NZG believed that it was not creating Minahasa, but recreating it in a new Christian form. De wedergeboorte van een volk — "the rebirth of a people" - was how one missionary described the process. ${ }^{44}$

The idea of a single Minahasan volk was disseminated through new social institutions which, because they encompassed Minahasa as a whole, automatically helped to make that idea credible. The most important such institution was the local mission school system, the most extensive anywhere in the nineteenth-century Netherlands Indies. ${ }^{45}$ This system eventually came to feature a single curriculum and a single corps of Minahasan teachers trained at a central training college. ${ }^{46}$ There was also a single preferred medium of instruction, Malay, which transcended local linguistic rivalries and became the language of Minahasan unity.

Contact with the teachers, and instruction in Minahasan history and geography, enabled schoolchildren to perceive themselves as members of a Minahasan community, even when their own social circles were otherwise still much more local. Another NZG institution, the mission newspaper Tjahaja Sijang or Light of Day, performed an analogous integrative role for adults. First published in 1868, it was subtitled "Newspaper for Minahasa" and treated all Minahasan news as home news. ${ }^{47}$ Anderson has emphasized the importance of schools

41 Graafland, De Minahassa, 1: 134, 227, 342, 346, 370; ibid., 2: 199; R. Grundemann, Johann Friedrich Riedel: ein Lebensbild aus der Minahassa auf Celebes (Gutersloh: Bertelsmann, 1873), p. 244.

42 Tjahaja Sijang, March 15, 1905; Schwarz, Tontemboansche teksten, 2: 259-62; N. Graafland, "Indrukken en gedachten op de tentoonstelling, te Tomohon, 22 en 23 Julij 1874," Mededeelingen vanwege het Nederlandsch Zendelinggenootschap 19 (1875): 1-33, pp. 30-33; H. Kroeskamp, Early Schoolmasters in a Developing Country (Assen: Van Gorcum, 1974), pp. 192-93.

43 Reproduced in Tjahaja Sijang, October 1, 1921.

44 H. Rooker, quoted by E.A.A. de Vreede in "De uitgroei van het zendingswerk in de Minahassa tot de huidige kerk," De Opwekker 80 (1935): 329-350, p.340.

$45 \mathrm{It}$ is estimated that by 1870 almost all Minahasan boys between 6 and 14 years old, and over half of the girls in the same age bracket, were registered pupils (Kroeskamp, Early Schoolmasters, p. 129).

46 Kroeskamp (ibid., pp. 98-296) describes the development of mission education in Minahasa.

47 The story of Tjahaja Sijang, which was still being published in 1925, is told by A.B. Lapian in "Tjahaja Siang (The Light of Day): Its Significance for the History of the Indonesian Local Press," in Proceedings, Seventh IAHA Conference, 22-26 August 1977 (Bangkok: International Association of Historians of Asia, 1979). 
and printed media in defining the Indonesian nation at a later date. ${ }^{48}$ In Minahasa, these processes were already at work on a smaller scale in the nineteenth century.

The colonial government also contributed to the creation of a perceived Minahasan community. Its administrative policies, for instance, created a newly privileged elite of chiefly families which intermarried increasingly with each other, across walak boundaries, in order to maintain their status. ${ }^{49}$ In 1865 the state followed the mission example by providing a central training school for its Minahasan officials, including clerks and coffee supervisors as well as administrative chiefs. ${ }^{50}$ The main language of administration, as of proselytization, was Malay, although knowledge of Dutch also became widespread among the Minahasan elite. ${ }^{51}$ In combination with linguistic unification and Pax Neerlandica, the dense road network built to transport the coffee harvests gradually gave more substance to the perceived community by facilitating contact and movement between the walak..$^{52}$ At the conceptual level, European government spokesmen introduced Minahasans to an ideal of material and economic progress which complemented the ideals of social unity and spiritual enlightenment promoted by the mission. 53

By the last decade of the nineteenth century, articles by local writers in Tjahaja Sijang show that Minahasans themselves had learned to speak the same language.

I hope that the name of Minahasa will remain powerful for our children and our children's children. The benefits of the unity to which it refers are now plain to see. All we Minahasans, both government and people, are united in a fine endeavor. United in the cause of better roads, houses and economic activities for our profit and pleasure as Minahasans. And united above all in the quest for knowledge to guide us in this life and the next. ${ }^{54}$

This gentle nationalism was, to a large degree, designed and tailored by Minahasa's European masters. Nevertheless, it was also the partly unintended consequence of a set of real institutions which defined and created the community in which it took root. Furthermore, Minahasan nationalism was already developing a reactive, antagonistic dimension which brought it into conflict with its original sponsors.

\section{Ethnic Discrimination and Minahasan Identity}

European ambivalence toward Westernization among Minahasans was informed by prejudice and pride as well as genuine moral concern. Most missionaries could not accept Minahasans as equals, and saw any aspiration to equality as impertinent or even threatening. ${ }^{55}$ The earliest published expression of national feeling by a Minahasan came from an NZG employee, Lambertus Mangindaan, whose ambition to train as a missionary himself

\footnotetext{
48 Anderson, Imagined Communities, pp. 35-37, 110-12, 121.

49 Schouten, "De veranderende positie van het walakhoofd," pp. 63-65.

${ }^{50}$ Kroeskamp, Early Schoolmasters, pp. 227-32.

51 Schouten, "De veranderende positie van het walakhoofd," pp. 60-63.

52 Graafland, De Minahassa, 1: 179-80.
}

53 An example of this message is contained in an address by Resident A.J.F. Jansen to the Minahasan chiefs in 1859, reproduced in Panawuot, Minahasa lama dan baroe; moelai dari tjeritera-tjeritera doega-doegaan sampai pada tjeritera kedjadian-kedjadian baroe tentang kegerakan 2 kaoem dan tanah Minahasa (Manado, n.d. [1926]), Pp. 57-63.

54 F. Makelew in Tjahaja Sijang, September 6, 1895.

55 Schouten, "De veranderende positie van het walakhoofd," p. 63; M.H. Schippers, "Herinneringen uit mijn" vorige werkkring te Maoembi in de Minahasa," Mededeelingen vanwege het Nederlandsch Zendelinggenootschap 35 (1892): $131-47 ; 36: 201-16,420-32,3$ rd part, p. 430. 
had been frustrated by his European superiors despite his possession of a teaching qualification from the Netherlands. ${ }^{56}$ In 1873, Mangindaan wrote a historical article in which he portrayed the Tondano revolt of 1809 as the result of a "popular desire for liberation" among Minahasans. ${ }^{57}$ Members of the many walak which fought on the Dutch side in that conflict were described as "disloyal countrymen" whom the "magnanimous" rebels endeavored not to shoot in battle. ${ }^{58}$ For the first time, the ideal of Minahasan unity sponsored by the Dutch was being turned, at least figuratively, against them.

The secular colonial government was less hostile than the mission to the idea of cultural assimilation, but it too exposed its employees to treatment which encouraged them to identify with Minahasa rather than with the Dutch. "I have learned from experience that we natives are inferior beings in the eyes of a great many European officials," declared one of the most distinguished chiefs, Albert Lasut Waworuntu, after his retirement. ${ }^{59}$ The loss of political and economic autonomy which such men experienced during their transformation from walak leaders into district officials also rankled. ${ }^{60}$ When these disaffections coincided with broader public grievances, members of the chiefly elite sometimes acted to represent Minahasan interests against those of the local colonial state. In 1891, for instance, Waworuntu petitioned the governor-general in Batavia for an impartial investigation into the administration of Resident of Manado M.C.E. Stakman, whose reforms to the tax and corvée labor systems were unpopular with peasants and chiefs alike. ${ }^{61}$ Waworuntu signed the petition "in the name of the people of Minahasa, to which I am proud to belong."62

The role of racial stratification in defining the Minahasan nation was complicated by the fact that, if Minahasans were subordinate to Europeans, they were nevertheless becoming a lesser elite themselves as accessories to colonialism outside their homeland. The expansion of mission and later also state education in Minahasa generated a local surplus of literate, numerate manpower which was drawn off by government and private enterprise elsewhere in the Netherlands Indies. By 1930, around half of all Minahasans were literate-compared with fewer than 7 percent of all Indonesians-and one in every eight was living outside Minahasa. ${ }^{63}$ The experience of these expatriates as clerks in government offices, overseers on plantations, policemen in the colonial cities, and assistant missionaries in remote areas tended to reinforce a lesson which they had already learned at school-that as a Christianized, civilized people, Minahasans were "more elevated and illustrious" than the other

\footnotetext{
56 E.F. Kruijf, Geschiedenis van het Nederlandsche Zendelinggenootschap en zijne zendingsposten (Groningen: Wolters, 1894), pp. 390-91.

57 L. Mangindaan, “Oud Tondano," TBG 20 (1873): 364-77, p. 367.

58 Ibid., p. 368.

59 Handelingen Volksraad 1918: 206. A.L. Waworuntu (1862-1925) was decorated by the government in 1896 and appointed to the newly formed Batavia Volksraad in 1918-see L.F. van Gent, Nederland-Menado (1896-1921) (Weltevreden: Balai Poestaka, 1923), p. 86.

60 Schouten, De veranderende positie van het walakhoofd, pp. 66-97.

61 M. Schouten, "Myth and Reality in Minahasan History: The Waworuntu-Gallois Confrontation," Archipel 34 (1987): $119-41$.

62 Reproduced by M.C.E. Stakman in De Minahassa: bezwaarschrift, opgemaakt naar aanleiding van het rapport nopens den staat van zaken in de Minahasa, uitgebragt door W.O. Gallois, lid van den Raad van Nederlandsch-Indië (Amsterdam: Van Holkema, 1893), p. 113.

63 Calculated from the 1930 Volkstelling van Nederlandsch-Indië, 8 vols. (Batavia: Departement van Economische Zaken / Landsdrukkerij, 1933-1936), 5: 22, 89, 90, 122, 135, 141, 142, 208. No net literacy figure for all ethnic Minahasans is available, but a reconstructed rate of 45 percent for rural Minahasa alone represents a minimum estimate.
} 
natives of the Indies. ${ }^{64}$ The Minahasan status category, therefore, had a native floor as well as a European ceiling. As in the case of the Eurasians of the Indies, to whom Minahasans often compared themselves, the pride imparted by this knowledge enhanced group solidarity even if it did little to maintain the serviceability of Minahasa as a vehicle for selfless ideals.

One poignant manifestation of Minahasa's ambivalent position in the colonial order was a certain expansionist element in Minahasan nationalism. The whole island of Sulawesi became, for a time, the object of a subaltern form of imperialism among Minahasans. Between 1914 and 1920 the most important Minahasan political figure of the twentieth century, G.S.S.J. ("Sam") Ratulangie, educated son of a chiefly family from Tondano, called repeatedly for a pénétration pacifique of Celebes by Minahasans. ${ }^{65}$ The ultimate aim was to be "complete assimilation of North and Central Celebes to Minahasa," and although Dutch government support for this project was welcome, it would be first and foremost a "national mission" for Minahasa. ${ }^{66}$ But while some 10,000 Minahasans were living in other parts of Sulawesi by 1930 , only among Christian Sangir and Talaud islanders from the far north was there any tendency for members of other ethnic groups to assimilate to Minahasa. ${ }^{67}$ Elsewhere, the strength of existing identities, the condescending attitudes of the Minahasans themselves, and above all the increasing influence of Islam in most areas made this impossible. ${ }^{68}$

Ultimately, the colonial government itself also stood in the way of Minahasan imperial ambitions. By 1936 it was Dutch policy to dispense with Minahasan personnel in the "selfgoverning" states of Celebes as soon as suitably qualified local people became available. ${ }^{69}$ Apart from the fact that educational facilities outside Minahasa were improving, this policy also reflected a broad change in colonial attitudes to ethnic discrimination in the Indies. Except where European privileges were concerned, the absolutist colonial state of the twentieth century was often opposed in principle to the kind of ethnic favoritism which had served imperial interests in the past. ${ }^{70}$ The most striking illustration of how this affected and enhanced Minahasan nationalism concerns a special group of emigrants, those who served in the Dutch colonial army. ${ }^{71}$

Institutionalized racial discrimination had reached its apogee in the army, where the intermediate status of the Minahasans or "Manadonese" between European and other Indo-

\footnotetext{
64 The phrase is from Graafland's schoolbook Inilah kitab batja (1863), p. 5.

65 G.S.S.J. Ratulangie, "Het Minahassisch ideaal," Voordrachten en Mededeelingen, Indische Vereeniging 9 (1914): $31-$ 45, pp. 43-45; idem with F. Laoh, "De Minahassers in de Indische beweging," Koloniaal Tijdschrift 6 (1917): 46778, pp. 476-77. G.S.S.J. Ratulangie (1890-1949), now an Indonesian national hero, is the subject of a biography by W.S.T. Pondaag, Pahlawan kemerdekaan nasional Mahaputera Dr. G.S.S.J. Ratu Langie (Surabaya: Badan Penerbitan Dr. G.S.S.J. Ratu Langie, n.d. [1966]).

66 G.S.S.J. Ratulangie, "Minahassa perspektieven," De Taak 3 (1920): 125-27, p. 126.

67 Volkstelling, 5: 22; Ratulangie and Laoh, “De Minahassers in de Indische beweging," p. 476.

68 In 1923, the Islamic modernist organization Sarekat Islam even staged its own "National Celebes Congress" in Manado (Tjahaja Sijang, August 4, 1923).

${ }^{69}$ J.H.R. Broeder, "Een en ander over de zelfbesturende landschappen op Noord-Celebes," De Indische Gids 58 (1936): 1005-1018, p. 1008.

70 See, for instance, the 1901 colonial ministry statement on law, race, and ethnicity reproduced by J.H. Carpentier Alting in his Regeling van het privaatrecht voor de inlandsche bevolking in de Minahassa-districten der residentie Menado (Batavia: Landsdrukkerij, 1902-1903), vol. 1, pp. iii-v.

${ }^{71}$ Minahasans first fought for the Dutch overseas in 1829, during the Java War (Van Gent, Nederland-Menado, pp. 10-11). In 1920 they formed 15 percent of the colonial army (Koloniaal Verslag 1921, Appendix C, p. 5).
} 
nesian troops was regulated with military precision and affected everything from food to pensions. ${ }^{72}$ Simultaneously hailed as a martial elite among natives and frustrated in their aspiration to equality with Europeans, the Minahasans in the barracks of the Indies formed tight communities isolated from other groups by ethnic pride and jealousy. ${ }^{73}$ It was members of such a community at the Magelang military base in Central Java who founded the first formal Minahasan nationalist organization, the Perserikatan Minahasa or Minahasa Association, in 1909.74 "Our Minahasan troops," wrote a Dutch officer in 1917, "always give me the impression that they could form a danger, that they will preserve and extend their privileges at all costs."75 Faced with a plan to abolish their special status in 1919, Minahasan soldiers angrily petitioned the governor-general for immediate legal "equalization" - gelijkstelling - of all Minahasans with Europeans. ${ }^{76}$ At the same time the leader of this campaign, J. H. Pangemanann, insisted that gelijkstelling was not synonymous with naturalization, and that Minahasans wished emphatically to remain Minahasans.77 Having something in common to lose proved as effective a stimulus to Minahasan patriotism as having something in common to gain.

\section{Minahasa as a Political Cause}

The gelijkstelling petition brought Minahasans into unusually direct confrontation with the colonial government, not least because Pangemanann was a member of the Indische Sociaal-Democratische Vereniging, the forerunner of the Indonesian Communist Party, as well as vice chairman of Perserikatan Minahasa. ${ }^{78}$ Nevertheless, it was also the continuation of a long tradition of peaceful political protest. As early as 1877, the Minahasan district chiefs had appealed jointly to Batavia against legislation designating all uncultivated land in Minahasa as state domain. ${ }^{79}$ This first political action was unsuccessful, but Waworuntu's above-mentioned protest of 1891 ultimately led to the dismissal of Resident Stakman, the highest Dutch official in North Celebes. ${ }^{80}$ At the turn of the century Waworuntu and two other disaffected chiefs found an ally in a socialist member of the Netherlands parliament, H. Van Kol, whom they advised-incorrectly-that Minahasa was in a state of serious

\footnotetext{
72 B. van Kaam, Ambon door de eeuwen (Baarn: De Toren, 1977), pp. 42-47. The Manadonese, including a small number of Sangir islanders, formed the greater part of the "Ambonese" component of the army.

${ }^{73} \mathrm{~L}$. Balner, "Karakterschetsen van den Indischen soldaat, benevens practische voorstellen tot verbetering der keuringsresultaten," Indisch Militair Tijdschrift 56 (1925): 18-36, 83-100, 144-70, 222-41, 296-327, 3rd part, p. 164; C. Marcus, "Stroomingen in het leger," Indisch Militair Tijdschrift 50 (1919): 415-40, p. 417. The Manadonese did share their intermediate status with the Ambonese proper, but rivalry between the two groups was strong (Marcus, "Stroomingen in het leger,"p. 417).

74 Nafiri Minahasa, July 31, 1916, reproduced in P. Soeharto and A.Z. Ihsan, eds., Maju setapak: capita selecta ketiga (Jakarta: Aksara Jayasakti, 1981), p. 160. The association aimed to promote the mental and material welfare of Minahasans and to help and support members and their families-see De Koning, "De Vereeniging Minahasa," Orgaan der Nederlandsche Zendingsvereeniging 56 (1916): $29-30$.

75 In V 15/5/1918/64. This and all other official documents cited here are from the Algemeen Rijksarchief, Den Haag.

76 V 27/12/1921/A14X.

77 In Kilat (Magelang), May 20, 1919.

78 V 27/12/1921/A14X.

79 C.E. van Kesteren, “De 'vriendschap' der Indische regeering voor de bevolking der afdeeling Minahassa," De Indische Gids 1 (1879): 449-68, pp. 463-68.

${ }^{80}$ Schouten, "Myth and Reality," p. 132.
} 
unrest over excessive taxation and a draconian new interpretation of the state domain law. ${ }^{81}$ In 1912, finally, Perserikatan Minahasa joined with a group of teachers to protest against proposed cuts to local education in Minahasa-always a politically sensitive issue-and succeeded in persuading the government to water down the plan. 82

All of these actions had certain characteristics in common. Thanks to colonial education, the protests were framed in a language which the Dutch could understand-both literally, because they were written in Dutch, and metaphorically, because even the chiefs cast themselves as representatives (rather than, say, divinely appointed rulers) of the Minahasan volk, and appealed effectively to the Dutch sense of imperial duty and justice. This appeal was reinforced by a constant stress upon the essential loyalty of Minahasa to the Netherlands.

No! Minahasa does not ask to become a state in its own right. Minahasa wishes always to remain attached to the Netherlands, to become a part of the Netherlands, because Holland can bring Minahasa good fortune, provided only that what was promised in the contracts is not forgotten. ${ }^{83}$

The "contracts" referred to here were the various treaties concluded between the walak leaders and the VOC, and particularly the original agreement of 1679 , around which a whole mythology of "alliance" was developed. ${ }^{84}$ In reality, the 1679 treaty had only been one of a whole series confirming various North Celebes potentates as Company vassals, rather than allies, and neither it nor its later supplements promised Minahasans anything beyond protection from external enemies. ${ }^{85}$ Nevertheless, its perceived importance in the late nineteenth and early twentieth centuries reflected a genuine belief among Minahasans that colonialism was a contractual, reciprocal relationship which offered them rewards-spiritual enlightenment, material progress, and, above all, social prestige-as well as obligations. ${ }^{86}$ The petitioners of 1919 regarded the proposal to reduce them to the status of the Javanese as a breach of the colonial contract. 87

The gelijkstelling petition succeeded only in causing a rift within Perserikatan Minahasa, which then went into decline. 88 Minahasan military privileges were abolished as planned in 1921 , although a few were restored four years later. ${ }^{89}$ The soldiery, partly out of increased

\footnotetext{
81 Schouten, De veranderende positie van het walakhoofd, pp. 93-97; Van Kol, Uit onze koloniën, pp. 277-81; E.J. Jellesma, De Minahassa en eenige andere streken der residentie Menado (Amsterdam: De Bussy, 1903), pp. 5-9.

82 Gunning, "De protestantsche zending," pp. 513-15; Ratulangie and Laoh, "De Minahassers in de Indische beweging," pp. 468-69; T.F. Viersen, De invoering der onderwijs-reorganisatie in de Minahassa (Amsterdam: Blikman \& Sartorius, 1913); "Een Volksstem: een heftig protest van de Minahassa-Vereeniging' tegen de overplaatsing van het hoofd der Menadosche school," De School van Nederlandsch Indië 2 (1912): 522-23.

83 A.L. Waworuntu at a public meeting in 1902, quoted in Van Kol, Uit onze koloniën, p. 237.

84 See, for instance, the preface to Godée Molsbergen's Geschiedenis van de Minahassa (1928), published to commemorate the 250 th anniversary of the 1679 contract.

85 Godée Molsbergen (Geschiedenis van de Minahassa, pp. 90-94, 139-44) reproduces the supplementary treaties of 1699 and 1791 as well as the original. The equivalent agreements with neighboring regions are summarized by L.W. Alders, "Internationale rechtspraak tussen Indonesische rijken en de V.O.C. tot 1700" (doctoral thesis, Katholieke Universiteit te Nijmegen, 1955), pp. 83-88.

86 This was congruent with older assumptions about power and dependency as manifest in the custom of mekioki, an instrumental form of adoption practiced between adults-see L. Adam, "Zeden en gewoonten en het daarmede samenhangende adatrecht van het Minahassische volk," KITLV 81 (1925): 424-99, pp. 469-77.

87 This was made explicit by a Minahasan spokesman quoted in V 27/12/1921/A14X.

88 MR 779X/20; V 27/12/1921/A14X.

89 J. de Vries, "Het KNIL en de emancipatie van de inheemse bevolking van Nederlands-Indië, 1908-1942," (doctoraal scriptie, Rijksuniversiteit te Groningen, 1988), pp. 20, 30.
} 
realism, gradually became apolitical and conservative. Another reason why the crisis was soon overcome, however, was that the disappointing developments in Java coincided with new evidence of political progress in the homeland itself. In 1919 a representative council for Minahasa, the Minahasaraad, was inaugurated in Manado. With a direct system of election and an overwhelming indigenous majority, the Minahasaraad was the most democratic organ of government ever created in colonial Indonesia. ${ }^{90}$ Revised statutes adopted by Perserikatan Minahasa in 1918 had included the goal of loyaal streven naar zelfbestuur, "loyal pursuit of self-government," and the new council seemed to vindicate this paradoxical strategy. ${ }^{91}$

Presiding over local taxation and public services, the Minahasaraad abolished corvée labor, initiated a migration scheme to relieve local overpopulation, and involved itself in public health, markets, and credit services..$^{92}$ Exercising its right of petition to higher authority, it secured an extension of its own franchise from an initial 10 percent to almost 70 percent of the adult male population..$^{93}$ In its consultative capacity, it defended local education against more threats from above. ${ }^{94}$ Minahasaraad elections, meanwhile, were highly popular events in the local cultural context of endemic status competition and rivalry. ${ }^{95}$ Ratulangie, secretary of the council between 1924 and 1927, called it "an ultramodern body" and "an absolute success." 96 If the Japanese invasion had not intervened, progress toward political autonomy would have continued with the development of the Minahasaraad into a groepsgemeenschap or "group community" government for Minahasa. ${ }^{97}$

In economic terms, too, the twentieth century was kinder to Minahasa than the nineteenth. Compulsory coffee cultivation was abolished in 1899, whereupon this unpopular crop promptly disappeared from the Minahasan scene. Its place as staple export was taken by copra, good prices for which brought conspicuous prosperity to coconut growers. ${ }^{98}$ Even in those parts of Minahasa less suitable for coconut trees, a relatively even pattern of land ownership and a growing rice market precluded absolute poverty. ${ }^{99}$ The Great Depression

\footnotetext{
${ }^{90}$ There were 18 directly elected Minahasan members, one Chinese and four Europeans-see M. Brouwer, "Bestuursvormen en bestuursstelsels in de Minahassa" (doctoral thesis, Rijksuniversiteit te Leiden, 1936), p. 102, and J. Tideman, memorie van overgave as resident of Manado, February 23, 1926, pp. 59-63. Other regional councils were elected by means of stepped voting systems (V 27/10/1938/20).

91 Nafiri Minahasa Celebes (Batavia), October 10, 1918. Perserikatan Minahasa had petitioned the government for such a council in 1917 (V 11/3/1919/36).

92 Brouwer, "Bestuursvormen," pp. 112-13, 116; Tideman, memorie van overgave, pp. 86-88; M. van Rhijn, memorie van overgave as resident of Manado, May 12, 1941, pp. 56-57.

93 A.P. van Aken, memorie van overgave as resident of Manado, May 9, 1932, p. 51. A high initial income qualification was lowered in 1929 to give every adult male taxpayer the vote (Brouwer, Bestuursvormen, pp. 102103; MR 3204/1928).

94 Tideman, memorie van overgave, p. 156; MR 2955/1924; MR 23/1927.

95 Turnout was 76,71 and 68 percent in the elections of 1930,1934, and 1938 respectively_-Herziening van het kiesrecht voor den Minahassaraad," Locale Belangen 16 (1929): 880-86, p. 883; Van Rhijn, memorie van overgave, p. 195.

96 G.S.S.J. Ratulangie, "De inlandsche gemeenteordonnantie voor de Minahassa," De Stuw 1/17 (1930): 9; "Herziening van het kiesrecht," p. 883.

97 Van Rhijn, memorie van overgave, pp. 229-35; V 27/10/1938/20.

98 "Copra in de Minahassa," Economisch Weekblad voor Nederlandsch-Indië 1 (1932): 630-32, 669-70, 609-712, 76264, 811-13, 3rd part, p. 712; MR 779X/1920. In 1926, copra made up 90 percent of Minahasa's exports by value (Tideman, memorie van overgave, p. 116).

99 There are no landholding data for the Dutch period, but the 1963 agricultural census gives a high average farm size (1.74 ha) despite an unexceptional ratio of population to number of farms-see Sensus pertanian 1963,
} 
hit the Minahasan economy hard after 1930, but local and remitted salaries and pensions, which accounted for as much as 60 percent of the region's money income in 1932, cushioned the blow. ${ }^{100}$ The fact that most of these came from Dutch government and business sources helped to prevent any strong political reaction to the crisis.

Combined with Christianity and cultural Westernization, Minahasa's reputation for political loyalism earned it the epithet of "twelfth province" of the Netherlands. ${ }^{101}$ This loyalism was, however, a stylized and instrumental one calculated to further the interests of Minahasa as a nation or bangsa. A local newspaper article from 1929 compares the confrontational nationalism of Java and Sumatra, which "bangs and smashes at the government's door," with the more restrained-and effective-Minahasan variety.

Minahasa, which might be called sophisticated, is never slow to face the government either. But it comes respectfully, knocking on the door, requesting admission and asking that its wishes be granted. Those Minahasans who have some political awareness know how to make practical use of politics, know exactly what to do and how to behave in order to benefit their land and bangsa. ${ }^{102}$

Within Perserikatan Minahasa, which attracted many civilian as well as military members in the years before the gelijkstelling petition, bangsa Minahasa was explicitly perceived as a nation on the European model. ${ }^{103}$ At the inauguration of a civilian branch in the homeland in 1915, one speaker even exhorted Minahasans to draw inspiration from the bloody patriotisms of the First World War.

Minahasa, my bangsa! Do not be discouraged by fatigue, adversity, ridicule or oppression. Look at what is happening in Europe, where each man so loves his bangsa that if he dies on the battlefield it is as if to say: take my worthless body, I fought to the death for the glory of my country and the good of my bangsa. ${ }^{104}$

"There is a sense of nationality, a Minahasan nationalism," confirmed Ratulangie in a Dutch language article published two years later. "Everything Minahasan, everything which involves a national ideal, is concentrated in Perserikatan Minahasa."105

\section{Christianity and Nationalism}

Another part of the rhetoric of Minahasan nationalism was traceable directly to nineteenth century missionary discourse, and its central message was that of unity.

\footnotetext{
publikasi ke 1 (Jakarta: Biro Pusat Statistik, n.d. [1964]), p. 17. Tax statistics from Verslag van den belastingdruk op de inlandsche beoolking in de buitengewesten (Weltevreden: Landsdrukkerij, 1929), p. 31, and from the Koloniaal Verslag for 1929 (Appendix S, Table IIIb) suggest that 21 percent of the population of Minahasa and Gorontalo earned more than $f .120$ in 1927, against 3 percent in Java.

${ }^{100}$ From a table of regional income estimates reproduced from an unknown source by G.S.S.J. Ratulangie in Maesa (Batavia) 11-12 (1935): 217.

101 The nickname was popularized by Dutch "Ethical" politician C.T. Van Deventer (V 27/12/1921/A14X).

102 A.M. Tareran in Fikiran, April 6, 1929.

103 V 27/12/1921/A14X. With some 10,000 members in 1917, Perserikatan Minahasa was the largest native association in the Indies after Sarekat Islam (V 15/5/1918/64; D. van Hinloopen Labberton, "De invoering van œen militie in Indië, welke rekening houdt met het karakter van den inlander en de stroomingen in de inlandsche maatschappij," Orgaan der Vereeniging ter Beoefening van de Krijgswetenschappen 1916-1917: 579-622, p. 604.

104 J.U. Mangowal, quoted in Nafiri Minahasa, July 31, 1916, and reproduced in Maju setapak, ed. Soeharto and Ihsan, p. 167.

${ }^{105}$ Ratulangie and Laoh, "De Minahassers in de Indische beweging," pp. 472, 473.
} 
So, brothers, friends, members of the association, and all who have pure Minahasan blood, think of your land and join the movement of your times. Grasp the banner of the association and march forward together. Show that we are truly united. Follow the example of the ancestors from whom we inherited the name Minahasa-unity, unified, united in all good and righteous endeavors, for the good of the association and for the love of our land and bangsa. 106

At the same time, Christianity also contributed to an emerging ideal of emancipation. The NZG had sometimes been at odds with the secular colonial authorities, and had not shrunk from publishing attacks on government policies in Tjahaja Sijang. 107 "Christianity produces loyal subjects," Graafland wrote, "but a people which understands the notions of right and justice must also be treated justly." 108 The mission did much to create a political culture in which the legitimacy of loyal dissent was taken for granted. ${ }^{109}$ In the ecclesiastical sphere, it went further by supplying a vision of independence from Dutch leadership.

Despite their hostility to the idea of training Minahasan pastors immediately, most missionaries agreed that their ultimate goal was to make themselves redundant by creating an autonomous Minahasan church. ${ }^{110}$ After 1875, however, financial difficulties forced the NZG to transfer its Minahasan congregations to the care of the state Indische Kerk. ${ }^{111}$ For half a century the church in Minahasa became a rigid appendage of the colonial government. ${ }^{112}$ Yet much of the school system remained in mission hands, and Minahasan teachers at the NZG schools, most of whom remained lay preachers too, kept the ideal of ecclesiastical independence alive through their organization Pangkal Setia. ${ }^{113}$ Resentment also persisted among some Minahasan employees of the Indische Kerk itself. In 1933 members of both groups founded an independent national church called Kerapatan Gereja Protestan Minahasa (KGPM), the Minahasa Protestant Church Union. ${ }^{114}$ The Indische Kerk now accelerated its own belated autonomy program, and the established church in Minahasa received formal independence in 1934 as Gereja Masehi Injil Minahasa (GMIM), the Minahasan Evangelical Protestant Church. ${ }^{115}$ GMIM, with its great institutional momentum, remained

106 J.F. Rawung, second secretary of Perserikatan Minahasa, in Tjahaja Sijang, September 19, 1923.

107 Grundemann, Johan Friedrich Riedel, p. 168; Gunning, “De protestantsche zending," p. 471; De Vreede, "De uitgroei van het zendingswerk," p. 338; Graafland, De Minhassa, 2: 393. Tjahaja Sijang continued the tradition of dissent after its transfer to wholly Minahasan editorship in 1920 (Lapian, "Tjahaja Sijang," pp. 918-20).

108 Graafland, De Minahassa, 2: 135.

109 This atmosphere was probably unique in the colony, and certainly made a strong impression upon Javanese observers-see Prijohoetomo, "De Minahassa," Oedaya 85 (1930): 72-74.

110 "De opleiding der gemeenten in de Minahassa tot meerdere zelfstandigheid," Mededeelingen vanwege het Nederlandsch Zendelinggenootschap 11 (1867): 83-96, p.83; H.J. Tendeloo, "Eene nieuwe bijdrage tot de kennis van den aanleg en het karakter der Minahassers," Mededeelingen vanwege het Nederlandsch Zendelinggenootschap 11 (1867): 164-225, p. 187; I.P.C. van 't Hof, "Overzicht van de geschiedenis der kerk in de Minahassa," De Heerbaan 4 (1951): 234-38, 296-300, 330-35; 5 (1952): 117-30, 158-69, 4th part, p. 123.

111 Van 't Hof, "Overzicht," p. 118.

112 Van 't Hof, "Overzicht," pp. 117-28; De Vreede, "De uitgroei van het zendingswerk," pp. $344-47$.

113 As early as 1892, two NZG teachers pressed for the appointment of Minahasan pastors (H.M. Taulu, 125 tahun Kweekschool-SPGK Kuranga-Tomohon, 1851-1976 [1976], p. 7; De Vreede, "De uitgroei van het zendingswerk," p.343). Pangkal Setia was inaugurated in 1910 (M. Schouten, personal communication). 114 Fikiran, June 10, 1933; A.B. Lapian, “Gerakan Kristen revolusioner sampai 1942," Prisma 11 (1985): 86-96, pP. 94-95.

115 "Algemeen Reglement der Minahassische protestantsche kerk," De Opwekker 80 (1935): 55-73; D.M. Lintong, "Ds. A.Z.R. Wenas, ketua synode GMIM (1942-1967)" (sarjana thesis, Universitas Kristen Indonesia, Tomohon, 1978), p. 27. 
preponderant, but KGPM grew rapidly and included 61 congregations by $1941 .{ }^{116}$ The KGPM leader, B.W. Lapian, retained close links with secular nationalism in the form of Persatuan Minahasa, a political party created by Ratulangie and other intellectuals to replace the civilian wing of Perserikatan Minahasa in 1927.117

\section{Philippine Parallels}

While Javanese intellectuals of the early twentieth century often looked to the nationalist movement in British India for inspiration, their Minahasan counterparts were more interested in the American Philippines. ${ }^{118}$ When future Philippine president Manuel Quezon-a personal friend of Ratulangie-met Batavia Minahasans on a visit to Java in 1934, the idea was even raised that Minahasa might one day secede from the Indies to join the neighboring republic. ${ }^{119}$ Despite the obvious differences in scale and timing, there are real historical parallels between Minahasa and the northern Philippines in the colonial period. In both cases many small traditional communities, unshielded either by a world religion or by an overcapping indigenous polity, were welded into unity by Christianity and a colonial state. In both cases, a genuine nationalism arose which was inspired partly by a frustrated ambition to assimilate into European society-an ambition with which it always remained in some tension-and partly by a European fascination with precolonial society. ${ }^{120}$ In both cases, Christianity was also a source of inspiration and the church a focus of nationalist unrest. ${ }^{121}$ In the early twentieth century, however, a dynamic equilibrium was in both cases established between colonialism and nationalism. This was achieved on the basis of economic welfare, educational progress, and representative institutions which sustained a sense of political progress. ${ }^{122}$

One major contrast, however, was that Christian Filipinos, although they too had to share their colony with other groups to whom they felt superior, constituted a large demographic majority with a virtual monopoly over the Philippine nationalist movement. Minahasans, on the other hand, not only found themselves part of a state in which the Moros-so to speak-made up 90 percent of the population, but also had to come to terms with nationalist ideas and organizations originating outside their own region.

\section{Minahasa and Indonesia}

Minahasan leaders were already alert to political conditions elsewhere in the archipelago in 1877, when they complained that neighboring territories, though less loyal and less profitable to the government than Minahasa, were not subject to the state coffee monopoly

116 Lapian, "Gerakan Kristen revolusioner," p. 95.

${ }^{117}$ MR 154X/1940; Blumberger, De nationalistische beweging, p. 306. After 1927, Perserikatan Minahasa became a purely professional organization for Minahasan soldiers.

118 Ratulangie's magazine Nationale Commentaren (Batavia, 1937-1941), for example, gave extensive coverage to Philippine affairs.

119 G.M.A. Ingkiwirang, interview, August 21, 1988. Ratulangie's friendship with Quezon is mentioned in Pondaag, Pahlawan nasional, p. 108.

${ }^{120}$ On the influence of the latter in the Philippine case, see J.N. Schumacher, "The Propagandists' Reconstruction of the Philippine Past," in Perceptions of the Past in Southeast Asia , ed. Anthony Reid and David Marr (Singapore: Heinemann, 1979), p. 267.

${ }^{121}$ Lapian draws attention to this parallel in "Gerakan Kristen revolusioner," pp. 87, 92-96.

122 It is interesting that only 14 percent of Filipinos were enfranchised in 1941-O.D. Corpuz, The Philippines (New Jersey: Prentice-Hall, 1965), p. 133. In quantitative terms, Minahasa was far more democratic. 
or the state domain law. ${ }^{123}$ In the twentieth century they began to look to Java, where, for instance, corvée labor was phased out more quickly than in Minahasa. ${ }^{124}$ Even the foundation of Perserikatan Minahasa in 1909 must have been connected with the establishment of military chapters of the new Javanese national organization Budi Utomo in the same year. ${ }^{125}$ Ethnic rivalry, however, and the determination not to be outdone by any other bangsa, was much more important than any interest in solidarity here. "Minahasans," as one writer bristled in 1922 at the suggestion that other groups were more patriotic, "can rival anyone in the Indies in love for their tanah air."126

When Douwes Dekker's Indische Partij began to suggest that all indigenous peoples actually shared one great common tanah air, the overt response from Minahasans was cautiously positive. ${ }^{127}$ Some of their motives here were still strongly ethnocentric, however. A quarter of a million strong among a population of more than fifty million, they sensed that their future might ultimately depend not upon Dutch protection, but upon the goodwill of their neighbors. ${ }^{128}$

Although I do not yet fully understand what the current developments mean, I feel it is time for us as children of Minahasa, which is part of the Indian archipelago, with our Minahasan blood which is also Indian blood, to think about our present and future stance toward this movement. We must beware of what might happen if, in times to come, we should find ourselves alone and isolated. We cannot afford to take a false step, we cannot risk becoming trapped. ${ }^{129}$

The Indische Partij ultimately lost the support of more popular sectional groups like Sarekat Islam and failed to form the nucleus of an Indonesian national movement. The really difficult choices for Minahasa were therefore postponed until the appearance of Sukarno's Partai Nasional Indonesia in 1927.

Some Minahasan students in Java played important roles in the youth movement from which the new unitarian nationalism of the PNI drew much of its strength. ${ }^{130}$ It is also well known that Ratulangie ultimately became a prominent Indonesian nationalist. In 1936 he sponsored the "Soetardjo petition," calling for independence for the whole colony within ten years, and in 1939 he led Persatuan Minahasa into Gabungan Politik Indonesia or GAPI, a concentration of Indonesian parties. ${ }^{131}$ These facts, however, represent only part of a more complex picture. An attempt to absorb Minahasan student groups into Indonesia Muda or

123 In the first petition to the governor-general, reproduced by Van Kesteren in "De 'vriendschap' der Indische regeering," p. 465.

124 A.L. Waworuntu, "De Minahassa en het Minahassavolk, 1679-1917," De Indische Gids 40 (1918): 651-65, p. 654.

125 Nagazumi, The Dawn of Indonesian Nationalism, p. 94.

126 In Tjahaja Sijang, June 7, 1922.

127 Several leading members of Perserikatan Minahasa were also involved in the Indische Partij (MR 779X/1920; V 20/5/1924/R6X).

128 The population of Minahasa was 241,909 in 1920 and 307,767 in 1930-see P.M.L. Tammes, "De biologische achtergrond van het bevolkingsvraagstuk op Noord-Celebes en de Sangihe- en Talaud-archipel," Tijdschrift voor Economische Geographie 31 (1940): 177-98, p. 190.

129 "J.J." in Tjahaja Sijang, October 20, 1923. Ratulangie expresses similar apprehensions in "Minahassa perspektieven," pp. 125, 127.

${ }^{130}$ Two of the seven speakers at the first Indonesian Youth Congress in 1926, for example, were Minahasanssee Laporan kongres pemuda Indonesia pertama di Weltevreden, 1926 (Jakarta: Takari, 1981).

131 Pluvier, Overzicht, pp. 83, 118, 136; Pondaag, Pahlawan Nasional, p. 26. 
Young Indonesia, for example, was unsuccessful, and a delegate from Indonesia Muda trying to recruit members in Manado was obliged to use the name Minahasa Muda instead. ${ }^{132}$ Nor did Persatuan Minahasa join Permufakatan Perhimpunan-Perhimpunan Politik Kebangsaan Indonesia or PPPKI, the federation of nationalist parties sponsored by the PNI in 1927.133

It is also striking that, although the unitarian nationalist parties Parindra and later Gerindo were present in Minahasa, they never had much support there despite an unusually tolerant local Dutch administration. ${ }^{134}$ Insofar as it was politicized along party lines, the Minahasaraad was dominated instead by Persatuan Minahasa, to which one half of its elected members belonged between 1934 and 1938.135 Persatuan Minahasa candidates also consistently won every seat on the Manado town council which had been created alongside the Minahasaraad in 1919.136 Persatuan Minahasa derived its popularity partly from its close attention to specific local issues-school funding, ecclesiastical autonomy, an unpopular state copra freight monopoly -and partly from its explicit appeal to Minahasan national sentiment. In 1940 two Minahasaraad members sympathetic to Gerindo founded a new party called Perserikatan Kaum Minahasa in order to give Leftist politics a similar ethnic cachet. ${ }^{137}$

Ratulangie explained his opposition to the PPPKI partly in terms of the latter's noncooperative stance, which was alien to Minahasan politics, and partly in terms of its interpretation of kebangsaan or nationality. "The peoples of Indonesia," he argued, "can be divided into territorial units, each with its own rights as a bangsa." 138

One reason for the central committee's refusal to join is that the PPPKI is based upon kebangsaan in name only. In reality its unity does not reflect the rights of each bangsa in Indonesia. The Sarekat Islam party and the PNI in particular, although they claim to act on the basis of kebangsaan, do not represent specific bangsa in the sense just explained. ${ }^{139}$

While some radical Minahasans in Java objected to this attitude, most regarded it as entirely natural. ${ }^{140}$ One newspaper correspondent in the homeland even opined that Minahasa should seek its own independence "with or without Indonesia-after all, Minahasa is a bigger country than, say, the Republic of Haiti."141

132 KAPAK [Kerukunan Antar Pemuda Kawanua], Sejarah perjuangan pemuda Maesa (Jakarta: DPP KAPAK Jaya, 1976), pp. 27-28; Fikiran, June 7, 1930.

133 Blumberger, De nationalistische beweging, p. 306.

134 MR 697X/1932; MR 1125X/1933; MR 389X/1938; MR 807X/1934. Three Gerindo candidates (Partindo had become defunct in 1936) were all unsuccessful in the local elections of 1938 (MR 444X/1939).

135 MR 740X/1935. The remainder, like all Minahasaraad members prior to 1930 , seem to have claimed no formal party affiliation.

136 Until 1939, when one independent candidate was elected (MR 426X/1940).

137 MR 426X/1940.

138 Ratulangie at a Persatuan Minahasa congress in May 1928, reported in Fikiran, June 23, 1928.

139 Fikiran, June 23, 1928.

140 Some of the dissenters formed a splinter group called Perserikatan Celebes in 1930, but this was successful only as a joint venture with local politicians in South Sulawesi (L.J.J. Caron, memorie van overgave as governor of Celebes and dependencies, December 14, 1933, pp. 14-16).

${ }^{141}$ Fikiran, June 11, 1932. 


\section{Federal Nationalism}

Ratulangie's own view in 1938, and the official standpoint of Persatuan Minahasa, was that there was no necessary contradiction between Minahasan independence and Indonesian unity.

The national unity of the Indonesian volk is a political unity. It rests upon the political will to form a unity and to be a political nation. With full recognition of the cultural and ethnic differences between the various groups, and of the political consequences of those differences, we must campaign strongly for the recognition, acceptance, and realization of the political unity of the component parts of the Indonesian volk. ${ }^{142}$

The only ideological way to reconcile the old Minahasan nationalism with the new Indonesian one, and the only practical way to allay Minahasan fears of domination by other more numerous bangsa, was federalism. Ratulangie always recognized Indonesia as a geographic and political unit-in fact, he was one of the first people to popularize the concept outside scientific circles. ${ }^{143}$ But in 1922 he was already insisting upon federalism as the basis for its political development, and in 1930 he assured a public meeting in Manado that "the organization of the future state must be based upon the federal principle, with full recognition of the rights of each autonomous bangsa within the Indonesian framework."144

Despite Ratulangie's protestations of Indonesian solidarity, a corollary of federalism was that Minahasans were much less skeptical than many other Indonesians toward the decentralisatie policy by which the Dutch claimed to be promoting the incremental emancipation of the indigenous peoples. The Minahasaraad, after all, was a product of this policy, and while Minahasans might criticize the Minahasaraad for its limited powers-Pangemanann called it a "farce" in 1919-few thought of denouncing it as an instrument of "divide and rule." 145 Minahasans also took a keen interest in the "Government of the Great East" created in 1938 to administer eastern Indonesia from Makasar, and in the groepsgemeenschap plan for Minahasa which was still pending in $1942 .{ }^{146}$ Despite formal acknowledgement by Persatuan Minahasa of a fundamental conflict of interests between sini and sana, or native and European, and despite the gradual erosion of Minahasa's elite status within the colonial order, Dutch policies never quite diverged sufficiently from Minahasan aspirations to radicalize Minahasan nationalism or to end the continuity and autonomy of Minahasan history. 147

\section{Regional Nationalism in Colonial Indonesia}

The Minahasan case confounds some common assumptions about nationalism and regionalism in colonial Indonesia. ${ }^{148}$ While the politically moderate character of Minahasan "regional" nationalism was certainly conditioned by an unusually benevolent colonial history, it would be incorrect to dismiss Minahasa's claim to its own national identity as reactionary or defensive in spirit. That claim preceded Indonesia's both historically and morally,

142 Nationale Commentaren, November 26, 1938.

143 Akira Nagazumi, "Indonesia' and 'Indonesians': semantics in politics," Asian Profile 1/1 (1973): 91-102, p. 96; Laporan kongres pemuda, p. 47.

144 Minahassa Reoue (Makasar), March 31, 1927; Fikiran, May 31, 1930.

145 Kilat, May 20, 1919.

146 Nationale Commentaren, February 3, 1940; Menado Bulletin, June 10, 1939.

147 Ratulangie made a public statement of his alignment with sini in Manado in 1930 (Fikiran, May 31, 1930).

148 These assumptions are admirably summarized by Pluvier, Overzicht, pp. 15, 81. 
and the federal idea represented an honest attempt to reconcile it with Indonesian nationalism. At the same time, Minahasan nationalism cannot be characterized as a "primordial" phenomenon either. Precolonial tradition, in fact, was a factor only in the minds of intellectuals who attempted to portray it as a tribal premonition of liberal democracy, and thus link it with the Minahasaraad. ${ }^{149}$ A wave of rather unrealistic cultural nationalism among some young educated Minahasans between 1930 and 1942, concentrating upon the belated promotion of the indigenous Minahasan languages, leant heavily upon Dutch missionary literature and ideas. ${ }^{150}$

In retrospect, it is easy to dismiss colonial Minahasa as a political anomaly, a privileged region with a vested interest in the kind of incremental, decentralized emancipation favored by the Dutch. But for Minahasans themselves, Indonesia was the anomaly. It was their misfortune that by 1942 their own vision of Indonesia as a federation of autonomous bangsa was not as widely shared as they might have wished. Even the Ambonese, often compared with Minahasans on the basis of their superficially similar colonial history, did not have such a strong sense of their own separate nationality. Although bangsa Ambon constituted a perceived community of sorts in the late colonial period, it was deeply divided between Christians and Muslims, weakly supported by Ambonese institutions, without a clearly defined national territory, and preoccupied even in the last years by stark questions of loyalty and disloyalty to the Dutch crown which would have seemed anachronistic in Minahasa. ${ }^{151}$ In North Sumatra, Christian Bataks enjoyed a somewhat clearer national consciousness generated by missionary institutions similar to those in Minahasa, but this was not reinforced by a representative body or a strong political party. ${ }^{152}$

More traditional in structure and outlook, the numerous non-Christian societies of the Netherlands Indies were mostly even less prone to ethnic nationalism. If precolonial Minahasa bore little resemblance to a nation, the same can generally be said of the other groups which Harsja Bachtiar has called the "old nations" of Indonesia. ${ }^{153}$ The memoirs of Prince Diponegoro, for instance, show that while he was much concerned with "the land of Java," his objective in the Java War was to conquer it, not liberate it from the Dutch, whom he did not even perceive as a collectivity. ${ }^{154}$ The best known hikayat from the Aceh War, conversely, is clear about the identity of the Dutch unbeliever, but makes no mention of Aceh. ${ }^{155}$ Furthermore, one of the crimes of which it accuses the Dutch is that they "treat everybody in

\footnotetext{
149 Fikiran, December 23, 1933; Menado Bulletin, September 14, 1939.

150 See, for instance, M.R. Dajoh, Streven naar ontplooiing van de Minahassische cultuur (Batavia: Maesa, n.d. [1937]), Pp. 27-34, 51.

${ }_{151}$ Richard Chauvel, Nationalists, Soldiers and Separatists: the Ambonese Islands from Colonialism to Revolt, 1880-1950 (Leiden: KITLV Press, 1990), pp. 1-171.

152 The religious movements in which this Batak nationalism found its clearest expression are discussed by J.R. Hutauruk, "Die Batakkirche vor ihrer Unabhängigkeit (1899-1942): Probleme der kirchlichen Unabhängigkeit ansgesichts der Problematik von Mission, Kolonialismus und Nationalismus" (doctoral thesis, Universität Hamburg, 1980). See also Lance Castles, "The Political Life of a Sumatran Residency: Tapanuli, 1915-1940" (PhD dissertation, Yale University, 1972), p. 173.

153 H.W. Bachtiar, The Indonesian Nation: Some Problems of Integration and Disintegration (Singapore: Institute of Southeast Asian Studies, 1974), p. 7. Bachtiar defines nations somewhat vaguely as "ethnic societal communities."

154 Anderson, Imagined Communities, p. 19.

155 H.T. Damsté, ed. and trans., "Hikajat Prang Sabi," BKI 84 (1928): 545-609.
} 
the same way: one cannot distinguish any more ... who is a slave, and who is a lord."156 There is little room here for the horizontal comradeship of an Acehnese nation.

Some of the larger ethnic peoples of Indonesia did nevertheless begin to develop their own national consciousness in the twentieth century. Javanese nationalism and its misrepresentation in the historical literature have already been mentioned, but a better comparison with Minahasa is perhaps the Sundanese example. As an "autonomous" province with its own representative council created under the decentralisatie programme in 1926, West Java acquired an official institutional shell to complement the unofficial one being built up from below by "Pasundan," a modern organization formed in 1914 to promote the "mental, moral and social development" of the Sundanese. ${ }^{157}$ Like Persatuan Minahasa, Pasundan was led by moderate intellectuals with Dutch educations and followed a cooperative nationalist policy concentrating primarily upon regional issues. ${ }^{158}$ Although Pasundan was closer to the unitarian nationalist movement than the Minahasan parties, its activities, combined with a sense of territoriality and a homogeneous culture expressed in a considerable local press, gave some Sundanese a polycentric understanding of Indonesia comparable to that current among Minahasans. ${ }^{159}$

\section{Conclusion}

The strength and character of Minahasan nationalism owed much to a specific experience of conversion to Christianity, but the Sundanese example shows that similar movements could also develop in the absence of religious transformation. If there is any broad analytic model which can illuminate the general phenomenon of regional nationalism in colonial Indonesia, then it must have to do with the uneven impact of modernization in time and space. It was local "islands" of mutually reinforcing modern institutions which tended to cradle nations narrower than Indonesia. In Minahasa, the mission school system, the local state and press, the Minahasaraad, Perserikatan and Persatuan Minahasa, and the two Minahasan churches all combined to generate and maintain the idea of an exclusive Minahasan community. And because they also embodied ideals of unity, progress, and autonomy derived mainly from Dutch sources, they made that community a national community. Where the framework of such institutions was less complete, as in Ambon or the Batak lands, or where the time lag between the crystallization of the local nation and the emergence of equivalent pan-Indonesian institutions was short, as in the Sundanese case, fissiparous tendencies were relatively weak. But in Minahasa, where the local institutional shell had its origins in the nineteenth century, the demotion from bangsa to sukubangsa or ethnic group was more difficult to face. Indonesia, for Minahasans, was not part and parcel of modernity. Minahasa itself had already served as the social vessel of modernization. Indonesia was only a problematic option faced by a people already welded into unity by a dramatic social transformation.

\footnotetext{
156 Ibid., p. 595.

157 Blumberger, De nationalistische beweging, p. 38.

158 Pluvier, Overzicht, p. 82; W. J. O'Malley, "Second Thoughts on Indonesian Nationalism," in Indonesia: The Making of a Nation, ed. J.A.C. Mackie (Canberra: Research School of Pacific Studies, Australian National University, 1980), pp. 608-9.

159 Pluvier, Overzicht, pp. 80, 82. Ratulangie enjoyed good relations with the Pasundan leaders, and even addressed a Pasundan congress in 1932 (Nationale Commentaren, November 26, 1938).
} 